\title{
Price Adjustment and Exchange Rate Pass-through
}

\author{
Michael B. Devereux \\ University of British Columbia \\ CEPR \\ James Yetman \\ Bank for International Settlements \\ University of Hong Kong \\ Hong Kong Institute for Monetary Research
}

July 2008

\begin{abstract}
This paper develops a simple theoretical model that can be used to account for the determinants of exchange rate pass-through to consumer prices. While recent evidence has found low estimates of pass-through in many countries, there is little consensus on an explanation for this. Our paper argues that sticky prices represent a key determinant of exchange rate pass-through. We make this argument in two stages. First, holding the frequency of price change constant, we show that our model calibrated to data from low inflation countries can reproduce the estimates of very low pass-through for these countries. The principal determinant of low pass-through in this case is the slow adjustment of prices. We then extend the model to allow the frequency of price change to be endogenous. Calibrating to a wider set of countries, including both low-inflation and high-inflation countries, we show that our model implies that exchange rate passthrough is increasing in average inflation, but at a declining rate. Performing the identical exercise on the data, we find a striking correspondence between the predictions of the model and those of the data.

* The authors thank seminar participants at the Hong Kong Institute for Monetary Research, Trinity College Dublin, the Reserve Bank of New Zealand, the University of Hong Kong, Hong Kong University of Science and Technology, the CEPR/HIEBS/HKIMR Conference on Deflation, Pegs and Capital Flows, and a referee for comments. Any remaining errors are the authors' responsibility. Devereux thanks SSHRC, the Royal Bank of Canada, and the Bank of Canada for financial support. The opinions expressed are those of the authors' alone and not the Bank for International Settlements.
\end{abstract}




\section{Section 1. Introduction}

A substantial empirical literature has shown that exchange rate changes are at best weakly associated with changes in domestic prices at the consumer level, in many different countries. The low degree of 'exchange rate pass-through' both at the disaggregated level, for individual traded goods prices, and more generally in aggregate price indices, has been extensively documented for low-inflation developed economies. ${ }^{1}$ In comparison, for many developing countries, especially those with a history of high inflation, pass-through is much higher (Calvo and Reinhart 2002). This paper develops a simple theoretical model of exchange rate pass-through. We show that it can simultaneously explain the finding of very low exchange rate pass-through for developed economies, while many developing economies experience high pass-through.

There is a substantial debate about the causes of low exchange rate pass-through. Campa and Goldberg (2005) differentiate ‘micro-economic’ from ‘macro-economic’ explanations. In the first category, low pass-through is ascribed to various structural features of commodity markets, such as pricing-to-market by imperfectly competitive firms (Corsetti and Dedola 2005), domestic content in the distribution of traded goods (Corsetti and Dedola 2005; Burstein, Neves and Rebelo 2003), the importance of nontraded goods in consumption (Betts and Kehoe 2001), or the role of substitution between goods in response to exchange rate changes (Burstein, Eichenbaum and Rebelo 2002). Others argue, however, that the failure of pass-through is a more macroeconomic phenomenon, related to the slow adjustment of goods prices at the consumer level (see, for example, Engel 2002).

\footnotetext{
${ }^{1}$ See Engel (2002) for a survey of evidence.
} 
The question of whether exchange rate pass-through is attributed to sticky prices or to more structural features of international trade is important. If pass-through is due to sticky prices, then it is likely to be dependent on the stance of monetary policy, as suggested by Taylor (2000). This would have implications for the appropriate way to conduct monetary policy in an open economy.

Our paper constructs an open economy model linking slow exchange rate passthrough to a slow rate of price adjustment in imported goods. In the model, consumer prices adjust to exchange rates gradually, due to staggered price setting. Shocks to world interest rates, domestic monetary policy, and the distribution technology for converting imports into consumption goods cause movements in the real exchange rate. We can describe the model in a two-equation dynamic system in domestic price inflation and the real exchange rate. We abstract from many structural factors that might limit passthrough. Modeling monetary policy as a 'Taylor-type' interest-rate rule, we can investigate how the stance of monetary policy affects exchange rate pass-through.

The model produces a theoretical pass-through coefficient, analogous to those estimated in empirical studies on exchange rate pass-through. Calibrating this coefficient, we produce a quantitative estimate of pass-through implied by the theoretical model, and find that this is very low - below 20 percent at quarterly frequency - as is found in empirical studies for most OECD economies.

The contribution of the theoretical model is that it lets us conduct a quantitative accounting of the reasons for low pass-through. In our model, incomplete pass-through arises for two reasons - sticky nominal prices, and real (distribution technology) shocks. For our baseline calibration, we find that sticky prices are by far the most important 
factor in accounting for low pass-through. Eliminating all real shocks would increase pass-through by about one percent. But allowing all prices to be flexible would increase pass-through from 0.18 to 0.8 .

While nominal price stickiness is important in explaining low exchange rate passthrough, the distribution of shocks is also important. If shocks are too persistent, passthrough is very high, even in the presence of sticky prices. Apparently, low pass-through comes from a combination of price sluggishness and relatively transitory shocks.

In estimating exchange rate pass-through across a wide cross section of countries, however, we have to take account of the possibility that the degree of price rigidity may vary considerably, due to the widely different inflationary experiences. We therefore extend the model to allow the frequency of price changes to be chosen by firms. For a given cost of price changes (e.g. menu cost), firms will choose a higher frequency of price adjustment the higher is the average inflation rate. And the higher is the frequency of price changes, the greater is exchange rate pass-through.

We calibrate the model and shock processes for a large sample of countries, both developed and developing, and use our simulated model to compute theoretical passthrough coefficients for each country. Using the methodology of Ball, Mankiw and Romer (1988), we then ask how these artificial estimates of exchange rate pass-through will depend on the inflationary environment in our simulated model. Our estimates show that exchange rate pass-through is positively related to average inflation, but the relationship is non-linear - the sensitivity of pass-through to inflation falls the higher is the rate of inflation. 
As an empirical validation of the model, we perform the same regression exercise on the sample data, estimating aggregate pass-through coefficients for each country. We show that these estimated coefficients have a very similar relationship with average inflation as do the simulated coefficients in the theoretical model. In both cases, an increase in average inflation increases pass-through, but at a declining rate. These results suggest that the presence of nominal rigidities is an important element in the understanding of low exchange rate pass-through for low and stable inflation countries.

The paper is related to a growing literature on models of exchange rate passthrough and monetary policy. Monacelli (2005) provides an early analysis of how optimal monetary policy in an open economy with low exchange rate pass-through differs fundamentally from that of a closed economy. Devereux, Lane and Xu (2006) analyze the interaction between pass-through and financial constraints for monetary policy in emerging market economies. Flamino (2007) shows that low pass-through worsens the trade-off between output and inflation stabilization. Choudhri and Hakura (2006) shows that estimated exchange rate pass-through tends to vary systematically with the mean inflation rate. Choudhri, Faruqee, and Hakura (2005) is more similar to our paper in providing evidence that low pass-through is attributable to sticky prices and local currency pricing. Their model differs from ours in a number or respects, however, and does not endogenize the frequency of price adjustment.

The paper is structured as follows. In the next section we construct a model of price adjustment for an importing firm, assuming that the firm's frequency of price adjustment is exogenous and constant. We then integrate this into a model of a small open economy with an endogenous exchange rate. In section 3 we study the 
characteristics of exchange rate pass-through in this model, still holding the frequency of price adjustment fixed. In section 4 we extend the model to allow for the frequency of price adjustment itself to be endogenous. Section 5 contains some conclusions.

\section{Section 2. The Model}

\subsection{A model of price setting in imported goods}

Assume a large number of importing firms, each of which purchases a differentiated consumer good from abroad, and sells it to local consumers. All differentiated imported goods have the same foreign currency price, $P_{t}^{*}$. Each firm is a monopolistic competitor with constant elasticity of substitution $\lambda$. Firm $i$ selling to the domestic market faces demand given by

$$
C_{t}(i)=\left(\frac{P_{t}(i)}{P_{t}}\right)^{-\lambda} C_{t},
$$

where $P_{t}(i)$ is firm $i$ 's price, and $P_{t}$ is the composite price index for imported goods.

The firm's profit is

$$
\Pi_{t}(i)=P_{t}(i) C_{t}(i)-S_{t} P_{t}^{*} \Theta_{t} C_{t}(i)
$$

where $S_{t}$ is the exchange rate, and $\Theta_{t}$ is a per-unit transportation or distribution cost faced by the importing firm. By assumption, the firm sets prices in terms of the domestic currency. ${ }^{2}$ If the firm could adjust its price in every period, it would set the price

$$
\hat{P}_{t}(i)=\frac{\lambda}{\lambda-1} \Theta_{t} S_{t} P_{t}^{*}
$$

\footnotetext{
${ }^{2}$ See Devereux, Engel and Storgaard (2004) for the conditions under which the firm would want to keep its price constant in domestic currency. We also implicitly assume that there is full pass-through of exchange rate changes into the price of goods at the import level. Empirical evidence (e.g. Campa and Goldberg 2005) tends to support the conclusion that pass-through to imported goods is much higher than to the CPI.
} 
Now we follow Calvo (1983), in assuming a probability $1-\kappa$ that the firm changes its price at any period, and thus a probability $\kappa$ that the firm's price will remain unchanged, no matter how long it has been fixed for in the past. For constant $\kappa$, this is a model of time-dependent price setting. In the aggregate, firms will adjust their prices at a constant rate. The underlying rationale behind time-dependent price setting is that there are costs of price adjustment that make the firm averse to frequent price changes.

It should be noted that there are different specifications of time-dependent pricing commonly used in the literature. Yun's (1996) adaptation of the Calvo (1983) model allows firms to set prices which are automatically adjusted for anticipated inflation between explicit price adjustments. A slightly different specification is employed by Christiano, Eichenbaum and Evans (2005), who assume that prices are indexed to past rates of inflation. The underlying assumption in both cases is that the costs of price adjustment are related to information and contract re-negotiation, but not literally menu costs of nominal price adjustment. Some empirical evidence suggests that the costs of price change may be dominated by the former considerations (Zbaracki et al 2004).

On the other hand, Woodford (2003) and many other authors assume that firms must set nominal prices in advance, and do not index these to anticipated inflation. As argued in Woodford (2003), the theoretical case for price stability as a monetary policy objective is tied to the assumption that firms do not automatically fully index their prices to trend inflation in between periods of price adjustment.

Our model is based on the latter form of price adjustment rules. In this, we follow most models of state-dependent pricing (Ball and Mankiw 1994; Dotsey King and Wolman 1999; Lucas and Golosov 2007), which assume that firms cannot costlessly 
index their prices to anticipated or past inflation. If costless indexation were possible, then high (but stable) rates of inflation would not be associated with more frequent price changes.

The empirical evidence on the link between high (but stable) inflation rates and the frequency of price adjustment is mixed, because historically, most episodes of high inflation have also coincided with high inflation variability. For Canada, however, Fay and Lavoie (2002) find evidence that the frequency of wage contracts is negatively related to the average inflation rate as well as inflation uncertainty. Similar evidence for the US is presented in Vroman (1989). For Canada again, Christofides and Laporte (2002) find evidence that indexation of union contracts increases with higher inflation rates. Riksbank (2001) finds some tentative evidence that the frequency of price adjustment in Sweden fell due to the lower average inflation rate associated with inflation targeting. More indirectly, the results of Ball et al. (1988) point to the importance of menu costs over and above information and processing costs of price change. Finally, Levin and Yun (2007) document a positive relationship between average inflation rates and measures of price flexibility using a number of separate measures of flexibility across countries and time. Hence, we tentatively conclude that overall, there is likely to be a positive link between the average inflation rate and the frequency of price adjustment. Indeed, the evidence presented below strongly indicates that, across countries, exchange rate pass-through is increasing in average inflation rates. If prices were automatically indexed to anticipated inflation, this should not be the case. ${ }^{3}$

\footnotetext{
${ }^{3}$ Note that if automatic indexing of prices to anticipated inflation was used as an alternative to increasing the frequency of price adjustment, the basic mechanism of our model would still exist, provided indexing became more prevalent at higher rates of inflation.
} 
The inter-temporal profit maximization condition of the firm may be approximated as a negative function of the expected squared deviation of the actual log of price $\tilde{p}_{t}(i)$ from the desired log price in each period (e.g. Walsh 1998). Thus the firm's objective function can be written as

$$
L_{t}=F+E_{t}\left[\sum_{j=0}^{\infty}(\beta \kappa)^{j}\left(\tilde{p}_{t}(i)-\hat{p}_{t+j}(i)\right)^{2}+\frac{(1-\kappa)}{\kappa} \sum_{j=1}^{\infty}(\beta \kappa)^{j} L_{t+j}\right] \text {, }
$$

where small case letters represent logs. Here $L_{t}$ represents the proportional difference between unconstrained profits, when the firm adjusts its price in every period, and actual profits, when the firm sets its price at time $t$ under the assumptions of the Calvo model. The total loss to the firm, $L_{t}$, is comprised of the immediate menu cost $F$, interpreted as the share of average profits going to price adjustment, and the expected discounted value of losses from having the newly set price $\tilde{p}_{t}(i)$ differ from the desired price $\hat{p}_{t+j}(i)$, plus the expected value of the loss function that applies when the firm changes its price again in the future, which happens each period with probability $1-\kappa$.

It is straightforward to show that the optimal price for the newly price setting firm obeys the recursive equation $\tilde{p}_{t}(i)=(1-\beta \kappa) \hat{p}_{t}+\beta \kappa E_{t} \tilde{p}_{t+1}(i)$. From the definition of $\hat{p}_{t}$, this implies that

$$
\tilde{p}_{t}(i)=(1-\beta \kappa)\left(\hat{\lambda}+s_{t}+p_{t}^{*}+\theta_{t}\right)+\beta \kappa E_{t} \tilde{p}_{t+1}(i),
$$

where $\hat{\lambda}=\ln (\lambda /(\lambda-1))$ and $\theta_{t}=\ln \Theta_{t}$.

All importing firms that adjust their price at time $t$ choose the same price. Hence we can write the price index for imported goods facing the home country as

$$
p_{t}=(1-\kappa) \tilde{p}_{t}+\kappa p_{t-1}
$$


Equations (2) and (3) together determine the degree of 'pass-through' from exchange rates to imported good prices. Note that, as $\kappa \rightarrow 0$, holding $\theta_{t}$ and $p_{t}^{*}$ constant, a given change in the exchange rate will cause an immediate, one-for-one rise in the price level. But for $\kappa>0$, a change in the exchange rate only partially affects the price level, since importing firms adjust prices slowly.

We may combine (2) and (3) to derive the following inflation equation for imported goods prices,

$$
\pi_{t}=\eta\left(\hat{\lambda}+\theta_{t}+q_{t}\right)+\beta E_{t} \pi_{t+1},
$$

where $\pi_{t}=p_{t}-p_{t-1}$ is the inflation rate, $q_{t}=s_{t}+p_{t}^{*}-p_{t}$ is the real exchange rate, and $\eta=(1-\beta \kappa)(1-\kappa) / \kappa>0$. This 'forward-looking' inflation equation is a cornerstone of New Keynesian models (e.g. Clarida, Gali and Gertler, 1999), but it would normally have the output gap (or marginal cost 'gap') as the driving force for inflation. Here, the real exchange rate plays this role. ${ }^{4}$ Imported goods inflation will be higher when the real exchange rate is higher than its flexible price equilibrium level, given by $-\left(\hat{\lambda}+\theta_{t}\right)$. The degree to which the real exchange rate can differ from its flexible price fundamental level depends on the degree of price rigidity. As $\kappa \rightarrow 0$, the parameter $\eta$ rises, and the deviation of the exchange rate from the flexible price fundamentals falls (i.e. $\left.q_{t} \rightarrow-\left(\hat{\lambda}_{t}+\theta_{t}\right)\right)$

\footnotetext{
${ }^{4}$ This specification has been used also by Devereux (2001), and Monacelli (2001).
} 


\subsection{Exchange rate determination}

The model of firm pricing behavior can be combined with a simple model of exchange rate determination in a small open economy. This model is completely

standard, and a full description is provided in Appendix 1. Here we focus on the essential elements of the model. We begin with the familiar uncovered interest rate parity (UIRP) relationship, written as a log-linear approximation:

$$
i_{t}=i_{t}^{*}+E_{t} s_{t+1}-s_{t}
$$

In addition, we assume an interest rate rule: ${ }^{5}$

$$
i_{t}=-\phi+\delta \pi_{t}+v_{t}
$$

where $\phi$ is a constant, and is a measure of the monetary policy bias. When $\phi>0$, the monetary authority attempts to hold the nominal interest rate below its zero-inflation steady state, on average. The monetary authority sets interest rates to respond to CPI inflation, with the elasticity of response given by $\delta$. Let $\delta>1$, so that the monetary authority follows a policy of increasing the ex-post real interest rate in response to a rise in current inflation. Finally, $v_{t}$ is an interest-rate shock to the policy rule.

Combining these last two equations gives

$$
\delta \pi_{t}+v_{t}=r_{t}^{*}+\phi+E_{t} q_{t+1}-q_{t}+E_{t} \pi_{t+1},
$$

where $r_{t}^{*}=i_{t}^{*}-E_{t}\left(p_{t+1}^{*}-p_{t}^{*}\right)$ is the foreign real interest rate.

\footnotetext{
${ }^{5}$ We do not derive this rule from a welfare optimizing monetary policy problem, but 'Taylor-type' interest rate rules of this sort have been used extensively in the recent literature, and are argued to approximate actual monetary policy behavior (see Clarida, Gali and Gertler, 1998). Woodford (2003) discusses the relation between interest rate rules and optimal monetary policy.
} 


\subsection{Equilibrium}

Equations (4) and (6) represent a dynamic system in domestic inflation and the real exchange rate. There are three stochastic shocks in equations (4) and (6): to the foreign real interest rate, the domestic monetary policy rule, and the importing technology. The solutions to the model depend on the time-series properties of the shocks. We make the following assumptions:

$$
r_{t}^{*}=\rho r_{t-1}^{*}+\varepsilon_{t}, \quad v_{t}=\gamma v_{t-1}+\varsigma_{t}, \quad \theta_{t}=\mu \theta_{t-1}+v_{t}
$$

where $0 \leq \rho<1,0 \leq \gamma<1,0 \leq \mu<1$, and $\varepsilon_{t}, \varsigma_{t}, v_{t}$ are i.i.d., mean-zero disturbances.

Using these assumptions, it is easy to establish that the solutions for inflation and the real exchange rate are

$$
\begin{gathered}
\pi_{t}=\frac{\phi}{(\delta-1)}+a_{1} r_{t}^{*}+a_{2} v_{t}+a_{3} \theta_{t}, \\
q_{t}=\frac{\phi(1-\beta)}{\eta(\delta-1)}-\hat{\lambda}+b_{1} r_{t}^{*}+b_{2} v_{t}+b_{3} \theta_{t},
\end{gathered}
$$

where the coefficients are defined in Table 1.

\begin{tabular}{|l|l|l|c|}
\hline \multicolumn{3}{|c|}{ Table 1. Coefficients in equations (7) and (8). } \\
\hline$a_{1}$ & $\frac{\eta}{[(\delta-\rho) \eta+(1-\rho)(1-\beta \rho)]}$ & $b_{1}$ & $\frac{(1-\beta \rho)}{[(\delta-\rho) \eta+(1-\rho)(1-\beta \rho)]}$ \\
\hline$a_{2}$ & $\frac{-\eta}{[(\delta-\gamma) \eta+(1-\gamma)(1-\beta \gamma)]}$ & $b_{2}$ & $\frac{-(1-\beta \gamma)}{[(\delta-\gamma) \eta+(1-\gamma)(1-\beta \gamma)]}$ \\
\hline$a_{3}$ & $\frac{\eta(1-\mu)}{[(\delta-\mu) \eta+(1-\mu)(1-\beta \mu)]}$ & $b_{3}$ & $\frac{-\eta(\delta-\mu)}{[(\delta-\mu) \eta+(1-\mu)(1-\beta \mu)]}$ \\
\hline
\end{tabular}

Equations (7) and (8) describe the steady state rates of inflation and the real exchange rate, as well as the dynamic response of inflation and the real exchange rate to 
shocks coming from foreign real interest rates, domestic monetary policy, or the distribution technology.

The steady state rate of inflation and the steady state level of the real exchange rate are affected by two aspects of the monetary policy rule. First, if $\phi>0$, the monetary authority has a target for the nominal interest rate that is less than the steady state foreign real interest rate (normalized to be zero here). This implies that steady state domestic inflation must be positive in order to ensure a zero steady state domestic real interest rate (by arbitrage with the foreign real interest rate). Then from (4), this must mean a higher steady state $q$. In the presence of gradual price adjustment, the average real price set by price setters is eroded by inflation. Although prices and exchange rates increase at the same rate in steady state, the delayed response of prices to exchange rate changes implies that a rise in the inflation rate causes a steady state real exchange rate depreciation.

While the monetary policy parameter $\phi$ raises steady state inflation and the real exchange rate, the degree of 'tightness' of monetary policy, measured by $\delta$, has the opposite effect. A higher $\delta$ puts more weight on inflation in the monetary rule (5), and as a result reduces both steady state inflation and the steady state real exchange rate. ${ }^{6}$

A shock to the foreign real interest rate leads to a rise in inflation and a real exchange rate depreciation. The response to a shock to monetary policy is qualitatively equivalent to the response to a foreign real interest rate shock; an expansionary shock (a fall in $v_{t}$ ) also leads to a rise in inflation, and real exchange rate depreciation. The impact of a shock to the transport technology $\theta_{t}$ is different, however, and leads to a real 
exchange rate appreciation, as the domestic price rises relative to the foreign price. At the same time, because the shock is not permanent, this implies that the real exchange rate is expected to depreciate in the future. From the interest parity condition, this leads to a rise in domestic inflation.

\section{Section 3. The determination of exchange rate pass-through}

What does our model imply for exchange rate pass-through - i.e. the relationship between changes in the nominal exchange rate and the domestic price level? The degree of nominal price rigidity is a critical determinant of exchange rate pass-through. With fully flexible prices, the real exchange rate is independent of both interest rate and monetary policy shocks - so these shocks would generate full pass-through of prices to exchange rates. In that case, any incomplete pass-through would be fully attributable to shocks to the distribution technology. But when prices are sticky, money or interest rate shocks will also generate incomplete pass-through in the short run.

To explore the properties of pass-through, we solve for the price level and exchange rate. From the inflation equation (4), we can write the domestic price level as

$$
p_{t}=\frac{\phi}{(\delta-1)}+a_{1} r_{t}^{*}+a_{2} v_{t}+a_{3} \theta_{t}+p_{t-1}
$$

Using this and (8), we can determine the nominal exchange rate as

$$
s_{t}=\frac{\phi}{(\delta-1)}+\left(b_{1}+a_{1}\right) r_{t}^{*}+\left(b_{2}+a_{2}\right) v_{t}+\left(b_{3}+a_{3}\right) \theta_{t}-b_{1} r_{t-1}^{*}-b_{2} v_{t-1}-b_{3} \theta_{t-1}+s_{t-1}-\left(p_{t}^{*}-p_{t-1}^{*}\right) .
$$

Both equations display a unit root. Shocks to both the nominal exchange rate and the price level are permanent. However, the short-run dynamics of prices and the exchange

\footnotetext{
${ }^{6}$ A higher level of the monopoly markup $\hat{\lambda}$ leads to a steady state real appreciation, as it leads to a domestic price level that is on average higher than the foreign price. Note, however, that the markup parameter has no implications for the average inflation rate.
} 
rate may be quite different, due either to slow price adjustment, or the presence of technology shocks.

First focus on $r_{t}^{*}$ or $v_{t}$ shocks. From (9) and (10), the impact response of the exchange rate always exceeds that of the domestic price level, in absolute value. Thus short run exchange rate pass-through is incomplete, for interest rate or monetary policy shocks. Over time however, the response of $p_{t}$ converges to that of $s_{t}$, so that passthrough is complete in the limit. Only when prices are fully flexible $(\eta \rightarrow \infty)$ will the impact response of $p_{t}$ and $s_{t}$ to $r_{t}^{*}$ or $v_{t}$ shocks be identical.

In the case of $\theta_{t}$ shocks, pass-through is negative, since shocks to the transactions technology require a real appreciation. The price level rises, as the increased distribution cost is directly passed through to domestic prices, while the nominal exchange rate falls.

Can this model explain the low values of pass-through found in empirical studies for OECD economies? To address this question, we need a more precise definition of pass-through. We follow common practice from the literature and focus on the implied coefficient of a regression of inflation on exchange rate changes, adjusted for foreign inflation. Using (9) and (10), this may be written as

$$
\begin{aligned}
\frac{\operatorname{cov}\left(\Delta s_{t}+\Delta p_{t}^{*}, \Delta p_{t}\right)}{\operatorname{var}\left(\Delta s_{t}+\Delta p_{t}^{*}\right)}= & \frac{\left(a_{1}\left(a_{1}+b_{1}\right)-a_{1} \rho b_{1}\right)}{\left(1-\rho^{2}\right) \Omega} \sigma_{\varepsilon}^{2}+\frac{\left(a_{2}\left(a_{2}+b_{2}\right)-a_{2} \gamma b_{2}\right)}{\left(1-\gamma^{2}\right) \Omega} \sigma_{\zeta}^{2} \\
& +\frac{\left(a_{3}\left(a_{3}+b_{3}\right)-a_{3} \mu b_{3}\right)}{\left(1-\mu^{2}\right) \Omega} \sigma_{v}^{2},
\end{aligned}
$$

where $\Omega$ is defined as

$$
\begin{gathered}
\Omega=\left[\left(a_{1}+b_{1}\right)^{2}+b_{1}^{2}-2 a_{1} b_{1} \rho\right] \frac{\sigma_{\varepsilon}^{2}}{1-\rho^{2}}+\left[\left(a_{2}+b_{2}\right)^{2}+b_{2}^{2}-2 a_{2} b_{2} \gamma\right] \frac{\sigma_{\varsigma}^{2}}{1-\gamma^{2}} \\
+\left[\left(a_{3}+b_{3}\right)^{2}+b_{3}^{2}-2 a_{3} b_{3} \mu\right] \frac{\sigma_{v}^{2}}{1-\mu^{2}} .
\end{gathered}
$$


From expression (11), the implied pass-through coefficient will be a complex function of structural coefficients, the policy rule parameter $\delta$, the persistence of shocks, and the relative volatility of the shock processes.

How large will be the pass-through estimate implied by (11)? To answer this question we need realistic estimates of parameters and shock processes. First set $\beta=0.99$ to represent a quarterly frequency, and $\kappa=.75$ to represent full price adjustment on average every four quarters (here we continue to assume $\kappa$ is exogenous in the next section we allow $\kappa$ to be chosen by firms). We may measure the shocks as follows. Take $r_{t}^{*}$ as the real US interest rate, at quarterly frequency. This is constructed from the US T-bill rate, less ex-post quarterly inflation. At quarterly frequencies, we find this has persistence 0.87 and volatility given by $\sigma_{\varepsilon}^{2}=0.012^{2}$.

It is not clear how to estimate the monetary policy shock process, $\varsigma_{t}$. As is widely acknowledged, exogenous monetary policy shocks are difficult to identify. Clearly, our model incorporates a rather naïve monetary rule, in comparison to estimated Taylor rules (e.g. Clarida et al. 1998; Nelson, 2001). This rule will not closely fit interest rates very well in most countries, and so would imply a high degree of unexplained volatility in the estimates. Introducing a more realistic monetary rule, allowing for an output gap coefficient and interest rate smoothing, would greatly complicate the model equations. We compromise by taking an average of the coefficients on inflation in estimated versions of the Taylor rule from Clarida et al. (1998) to calibrate the coefficient $\delta$ at a value of 1.5. In addition, we restrict attention to the case where monetary policy shocks are i.i.d., so that $\gamma=0$. This accords with the specification of monetary policy shocks in the VAR literature (e.g. Christiano et al. 1999, 
2005). There are a number of approaches to calibrating $\sigma_{\varsigma}^{2}$. Estimates of volatility of monetary policy shocks in the VAR literature, such as Christiano et al. (1999) range from standard deviations of 0.5 to 1 percent. Choosing the high end of this range then gives $\sigma_{\varsigma}^{2}=.01^{2}$. Alternatively, we could calibrate $\sigma_{\varsigma}^{2}$ from measures of the residual variance found in empirical estimates of interest rate rules. Judd and Rudebusch (1998) estimate Taylor rules over three different monetary episodes in the US, and find an average standard deviation of shocks equal to 0.8 percent. But since their estimated rules include an interest rate smoothing term, it is necessary to scale this up by a factor $1 /(1$ $\rho^{2}$ ) in order to apply to our framework, were $\rho$ is the estimated coefficient on the interest rate rule. Doing this leads to an implied variance of $\sigma_{\varsigma}^{2}=.0097^{2}$ which is almost the same ${ }^{7}$. Hence we use the assumption that $\sigma_{\varsigma}^{2}=.01^{2}$. We also use alternative estimates of $\sigma_{\varsigma}^{2}=.005^{2}$ and $\sigma_{\varsigma}^{2}=.03^{2}$ in Table 2 , and find that the results for pass-through are quite insensitive to these differences.

For the distribution technology shocks, we assume that $\theta_{t}$ follows a process identical to estimated Solow Residuals from the international real business cycle literature. We justify this based on the assumption that shocks to the productivity of the distribution technology are similar to aggregate productivity shocks. The typical estimate in the IRBC literature (e.g. Backus, Kehoe, and Kydland, 1995) finds that the (detrended) productivity process has persistence about 0.7 and a standard deviation of 1 percent at a quarterly frequency. Hence, we assume that $\mu=0.7$ and $\sigma_{v}^{2}=.01^{2}$.

\footnotetext{
${ }^{7}$ In particular, they estimate standard deviations of $0.27,1.3$, and 0.84 across the different regimes, with the coefficient on the interest rate rule being, respectively, $0.72,0.56$, and 0.42 . Using the formula given
} 
Table 2 presents the value of exchange rate pass-through computed defined from equation (11), using these estimates. For the baseline case, pass-through is 0.175 . While this might seem surprisingly low, in fact it is close to recent estimates of exchange rate pass-through into the CPI in industrialized countries (e.g. Bailliu and Fujii 2004).

\begin{tabular}{|l|l|l|l|l|l|}
\hline Table 2. Pass-through coefficient from (11). \\
\hline Case & Pass-through & Mon. rules & Pass-through & $\kappa \rightarrow 0$ & Pass-through \\
\hline Baseline & 0.175 & $\delta=1.1$ & 0.18 & $\delta=1.1$ & 0.97 \\
\hline$\sigma_{v}^{2}=0$ & 0.177 & $\delta=2$ & 0.161 & $\delta=1.5$ & 0.807 \\
\hline$\rho=0.99$ & 0.895 & $\delta=2.5$ & 0.142 & $\delta=2$ & 0.56 \\
\hline$\sigma_{\varsigma}^{2}=0$ & 0.178 & $\delta=3$ & 0.123 & $\delta=2.5$ & 0.38 \\
\hline$\sigma_{\varsigma}^{2}=0.03^{2}$ & 0.138 & $\delta=5$ & 0.059 & $\delta=3$ & 0.262 \\
\hline
\end{tabular}

What accounts for the small size of exchange rate pass-through? Our model has no non-traded goods sector, pricing to market, or endogenous domestic input into the consumption of import goods (elements that have been argued to contribute to low exchange rate pass-through). In this model, the only factors that prevent full passthrough are a) slow nominal price adjustment, and b) the presence of shocks to the distribution technology. The first factor means that import prices adjust slowly to changes in exchange rates, while the second factor implies that the exchange rate may change without any automatic response of prices, even if nominal prices were flexible. In fact, for the baseline calibration, slow price adjustment is by far the most important factor. To see this, Table 2 illustrates the effect on pass-through of setting $\sigma_{v}^{2}=0$, so that sticky prices represent the only cause of imperfect pass-through. The implied passthrough coefficient changes only fractionally - from 0.175 to 0.177 . By contrast, with above, and averaging, gives $\sigma_{\varsigma}^{2}=.0097^{2}$. 
technology shocks as before, but with $\kappa=0$, so that prices are fully flexible, Table 2 shows that the pass-through coefficient rises to 0.81 .

Although sticky prices are necessary for low pass-through here, they are not sufficient. The degree of persistence in the shock processes also plays an important role. If the shocks to the foreign interest rate are very persistent, then pass-through would be much higher, since in that case, firms would adjust prices by much more in response to the shocks. Table 2 illustrates this, by setting $\rho=.99$. If all other parameter values are as before, the degree of exchange rate pass-through rises from 0.175 to 0.895 . Intuitively, for highly persistent shocks, inflation responds much more than for transitory shocks. Thus a combination of sluggish adjustment of nominal prices and non-persistent shocks combine to give empirically plausible measures of exchange rate pass-through.

How does our theoretical pass-through coefficient depend on monetary policy? The two parameters of monetary policy are $\phi$ and $\delta$. The pass-through coefficient (11) is independent of $\phi$, since for given $\delta$, this parameter just determines the average rate of inflation. ${ }^{8}$ In general, however, pass-through will depend on $\delta$. Table 2 illustrates this by varying $\delta$ over an empirically relevant range, between 1.1 and $3 .^{9}$ A lower (higher) value of $\delta$ will increase (reduce) the coefficient of exchange rate pass-through. But the size of this effect is quite small. Letting $\delta$ fall from 1.5 to 1.1 will increase pass-through from 0.175 to 0.18 . Letting $\delta$ rise from 1.5 to 3 reduces pass-through from 0.175 to 0.1 . Thus, the stance of monetary policy is not of major quantitative importance for exchange rate pass-through, holding the degree of price stickiness $(\kappa)$ to be constant. The intuition

\footnotetext{
${ }^{8}$ In the next section, when we allow $\kappa$ to be endogenous, this property no longer holds.

${ }^{9}$ Our solution does not admit values of $\delta$ below unity. Empirical estimates of $\delta$ are predominantly in the range 1 to 2.5 (Clarida et al. 1998).
} 
for this result is as follows. For interest rate shocks or monetary policy shocks, passthrough will not depend on the monetary rule $\delta$, because movements in $\delta$ affect both the exchange rate and the price level equally (c.f. equations (9) and (10)). For technology shocks, a rise in $\delta$ will reduce pass-through. However, as shown above, low passthrough is mainly due to sticky prices, with interest rate and monetary policy shocks.

But the relationship between pass-through and the monetary stance is more complicated if we depart from the baseline calibration above. Take $\kappa=0$, so that prices are fully flexible. Table 2 shows that if $\delta$ ranges from 1.1 to 3, as before, then with the shocks measured as before, the pass-through coefficient falls from 0.97 to 0.26 . With flexible domestic prices, tighter monetary policy causes a dramatic fall in the degree to which real exchange rate adjustment is achieved by domestic price movements, relative to exchange rate movements. ${ }^{10}$

In summary, our model can account for the low estimates of exchange rate passthrough in low inflation OECD economies. Moreover, pass-through is low principally because of slow price adjustment. But as we have noted above, low exchange rate passthrough is not a universal phenomenon. For many non-OECD economies, estimated exchange rate pass-through is much higher. To account for this within our model, we have to relax our assumption that the frequency of price change, $\kappa$, is exogenous, and independent of the characteristics of monetary policy and inflation. We address this in the next section.

\footnotetext{
${ }^{10}$ This relies on the presence of the distribution technology shocks. If there were no shocks requiring real exchange rate adjustment, then in the flexible price environment, pass-through is unity, whatever the value of $\delta$.
} 


\section{Section 4. Endogenous frequency of price adjustment}

So far, we have assumed that $\kappa$ is exogenous. In most studies of the effects of monetary policy on US data, a constant degree of nominal price rigidity is assumed. But to study exchange rate pass-through across a large group of countries, it is surely unrealistic to assume a common frequency of price adjustment. Our results below indicate a large range of estimates of exchange rate pass-through across countries. While pass-through is low for low-inflation OECD economies, for instance, for other higher inflation countries pass-through is much higher. To account for these differences, it is natural to suggest that the degree of price flexibility may systematically respond to the inflationary environment.

The theoretical argument for sticky prices is based upon some type of costs associated with price changes. There seems no clear reason to expect that these costs would differ substantially across countries, as a proportion of total operating costs. By contrast, the benefits from price flexibility probably vary widely across countries, due to large differences in inflation rates. It is reasonable to imagine that firms would choose to increase the frequency of price adjustment when inflation is higher, or more volatile.

In our model, the higher is the inflation rate, the more undesirable it is for a firm to fix its price in domestic currency, since its real price will be eroded by exchange rate depreciation. Thus higher average inflation should raise the frequency of price changes. Inflation uncertainty may also be relevant, since the more unpredictable is inflation, the higher is the likelihood that the firm's price will depart from the efficient price, giving it an incentive to adjust its price more frequently. 
With this in mind, we now extend the analysis to allow firms to choose their optimal frequency of price adjustment. This opens up an additional dimension by which exchange rate pass-through may differ across countries. In addition, it allows a separate channel by which monetary policy itself may influence pass-through.

\subsection{Solving the model when $\kappa$ is endogenous}

We assume that each firm chooses its $\kappa$ optimally, taking the $\kappa$ choice of all other firms as given. This approach to endogenizing the degree of price flexibility differs from the usual state dependent pricing model (see e.g. Dotsey King and Wolman 1999, Lucas and Golosov 2007). In typical state dependent pricing models, firms can change their prices at any time provided they pay a fixed cost, or `menu cost’. In our model, the choice is effectively over the average duration of price stickiness. As we discussed above, there is evidence that the duration of price stickiness is inversely related to the average inflation rate across countries and time periods. Hence, there is empirical support for the notion that $\kappa$ varies across environments. This may help to justify our methodology, since we wish to investigate the impact of differences across countries in average rates of inflation over time, rather than to document the high frequency response to inflation captured by state dependent pricing models.

In fact, the results would be very similar if we employed a more standard state dependent pricing model allowing for trend inflation differences. Levin and Yun (2007) follow the approach pursued here, allowing firms to change contract duration in a Calvo pricing framework. Following the analysis of Romer (1999) and Devereux and Yetman (2002), they describe a Nash equilibrium in which each firm within an industry chooses 
its contract duration given the parameter chosen by all other firms, and in equilibrium all firms choose the same duration. They find that the results of inflation rates in their model are similar to that in a more conventional state dependent pricing framework, such as Golosov and Lucas (2007).

The details of the problem faced by the firm are described in Yetman (2003). We assume $\kappa(i)$ is chosen by firm $i$ to minimize the unconditional mean of its loss function, given by ${ }^{11}$

$$
L_{t}(i)=\frac{(1-\beta \kappa(i))}{(1-\beta)}\left[F+E \sum_{j=0}^{\infty}(\beta \kappa(i))^{j}\left(\tilde{p}_{t}(i)-\hat{p}_{t+j}(i)\right)^{2}\right] .
$$

Because of the unit root property of prices and exchange rates, the quadratic terms inside the summation expression will depend only on the variance of the shock distributions, and not on the aggregate price level in the economy itself. To see this, note that from the solutions for the aggregate price level and the exchange rate, we may solve for the optimal newly set price for a firm $i$ in any given period as

$$
\tilde{p}_{t}(i)=c_{1}+c_{2} \theta_{t}+c_{3} r_{t}^{*}+c_{4} v_{t}+\left(s_{t}+p_{t}^{*}\right)
$$

where the coefficients are

$$
\begin{gathered}
c_{1}=\hat{\lambda}+\frac{\beta \kappa(i) \phi}{(\delta-1)(1-\beta \kappa(i))}, c_{2}=\frac{(1-\beta \kappa(i))+\beta \kappa(i) \mu\left(b_{3}+a_{3}\right)-\beta \kappa(i) b_{3}}{1-\beta \kappa(i) \mu}, \\
c_{3}=\frac{\beta \kappa(i) \rho\left(b_{1}+a_{1}\right)-\beta \kappa(i) b_{1}}{(1-\beta \kappa(i) \rho)}, c_{4}=\frac{\beta \kappa(i) \gamma\left(b_{2}+a_{2}\right)-\beta \kappa(i) b_{2}}{(1-\beta \kappa(i) \gamma)} .
\end{gathered}
$$

The loss function (12) can be approximated by summing over a large finite number of periods, for draws from given distributions of the shocks. Then the optimal

\footnotetext{
${ }^{11}$ Since our empirical analysis focuses only on cross-section data, we look only at the unconditional mean of $\kappa$. In general the fully optimal $\kappa$ will vary over time, as the shocks are persistent. While solving for
} 
$\kappa(i)$ is chosen to minimize the numerical value of the loss function. Recall from Table 1 that the parameters $a_{k}, b_{k}, k=1,2,3$, depend on the economy-wide value of $\kappa$. However, the individual firm does not take account of this dependence for its choice of $\kappa$. A Nash equilibrium obtains when all the firms within a given economy choose the same average frequency of price change, so that $\kappa(i)=\kappa$.

\subsection{A Quantitative Analysis of the model}

We now explore the model's quantitative implications for exchange rate passthrough, allowing for endogenous frequency of price adjustment as described in the previous section. We first calibrate the model parameters and shock processes for a sample of 119 countries, on a country-by-country basis. We then construct simulated data on inflation and exchange rate changes for each country using the calibrated parameters and shock distributions, while allowing for an endogenously determined $\kappa$. Then for each country $j$, we use the simulated data to estimate the exchange rate passthrough parameter $\beta_{j}$ :

$$
\Delta P_{t j}=\beta_{j}\left(\Delta S_{t j}+\Delta P_{t}^{*}\right)
$$

We then follow the methodology of Ball, Mankiw and Romer (1988) in investigating the theoretical relationship between the estimates of exchange rate pass-through and inflation rates from the simulated model. We can then repeat this exercise on the actual sample data, estimating the empirical coefficient of exchange rate pass-through for each country, and using the same cross-country regression procedure to describe the relationship between pass-through and inflation in the sample data. To the extent that the theoretical

the time-varying $\kappa$ is possible, it is considerably more involved than our approach, and would likely add little to the results. 
and empirical relationship between exchange rate pass-through and inflation is similar, we may infer a validation of our model.

\subsection{Model Simulation}

In order to simulate the theoretical model, we must calibrate the parameters and shocks. Unlike the calibration exercise in section 3, we are forced to use an annual frequency in order to study such a large sample of countries. Hence we set $\beta=0.96$. In addition, we assume an average mark-up of $10 \%$, so that $\hat{\lambda}=\ln (\lambda / \lambda-1)=0.10$. This is consistent with estimates for the US at least, and we have little evidence on the size of markups for most other countries. Consistent with the state-dependent pricing study of Dotsey et al. (1999), we assume that price-setting takes $4 \%$ of profits, so that $F=0.04$.

We calibrate the shocks using a similar approach as we used in section 3. First, we generate world real interest rates as the end of period US discount rate less the inflation rate in the CPI , but now at annual frequency. Again assuming the world real interest rate follow an $\mathrm{AR}(1)$ process, we get an estimate of $\rho=0.83$, and $\sigma_{\varepsilon}^{2}=2.0 \times 10^{-4}$.

The technology shock process is calibrated using national productivity data from the Penn World Tables (Heston, Summers and Aten, 2006). We use de-trended chained Real GDP per worker (RGDPWOK) as an estimate on national productivity shocks, and estimate $\mu$ and $\sigma_{v}^{2}$ assuming this follows an AR(1) process. Estimates of $\mu$ and $\sigma_{v}^{2}$ range from -0.55 to 0.66 and $1.0 \times 10^{-4}$ to $2.1 \times 10^{-2}$ respectively.

Then, to determine the remaining parameters $\left(\phi, \delta, \gamma, \sigma_{\varsigma}^{2}\right)$, we estimate a policy rule for each country in the same manner as described in the previous section. In particular, we set $\delta=1.5$, and choose a country-specific $\phi$ to match the average sample 
inflation rate for each country. The domestic nominal interest rate shock process ( $\gamma$ and

$\left.\sigma_{\zeta}^{2}\right)$ is then estimated from the annual deviations from the implied monetary policy rule, given the values of $\phi$ and $\delta$. Data for the nominal discount rate and the consumer price index inflation rate are taken from the IFS. Average $\gamma$ across all countries is 0.22 , and average $\sigma_{\varsigma}^{2}$ is $2.2 \times 10^{-2}$.

We include the largest possible number of countries for which all the required data is available for 10 or more years over the 1970-2007 period. This includes 119 countries, across all continents and degrees of economic development.

\subsection{Determining pass-through implied by the model}

For each country, using the calibrated parameter values and the $\kappa$ determined above, we construct a simulated time series for inflation and exchange rate change over 138 periods for each country. Pass-through is estimated from the simulated data in the manner described above over the final 38 periods (to be consistent with the following empirical evidence). 


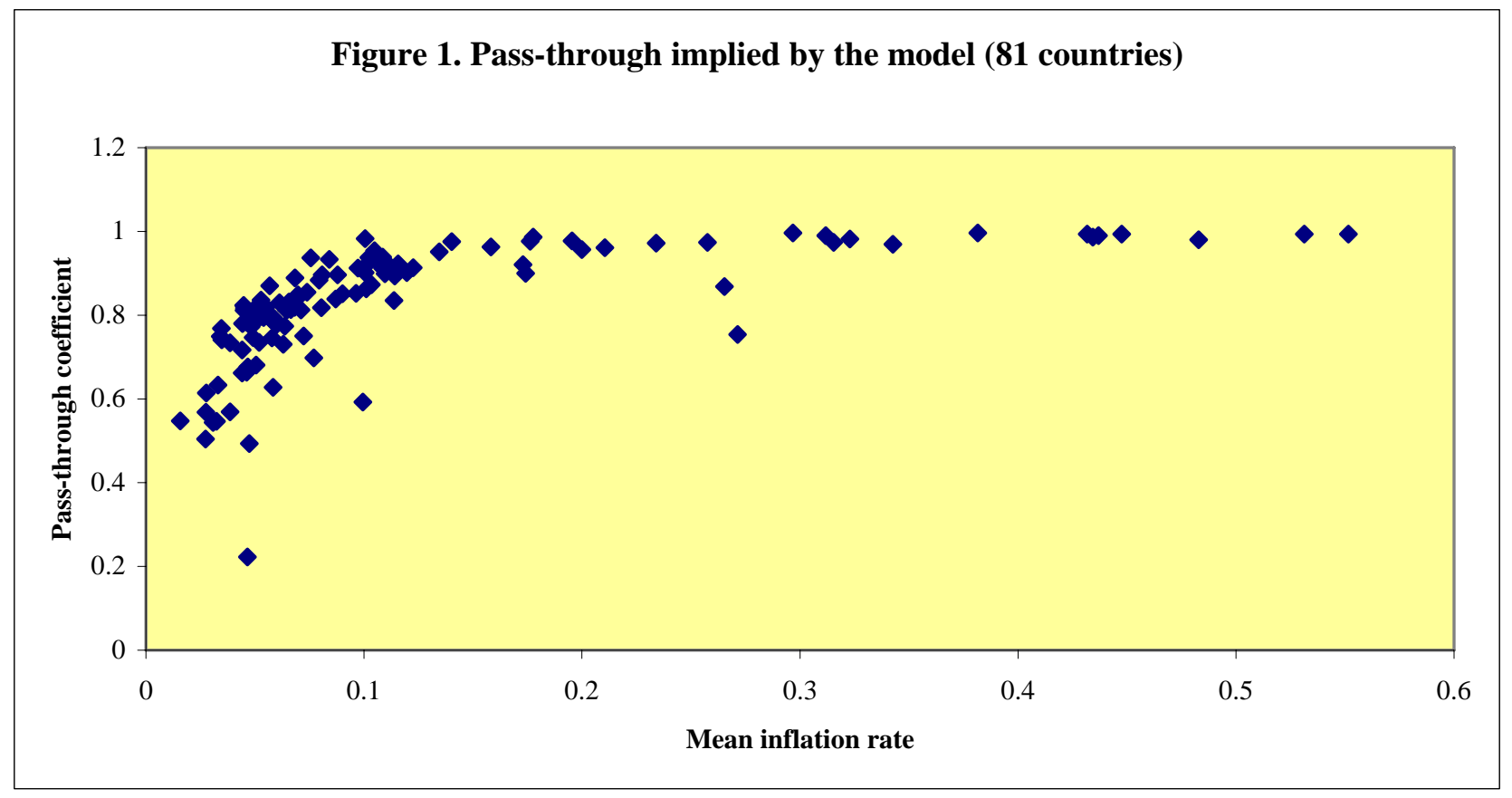

The quantitative relationship between domestic inflation and exchange rate passthrough $\left(\beta_{j}\right)$ is demonstrated in Figure 1. For countries with low inflation, exchange rate pass-through is generally far from complete. But for countries with much higher inflation rates, we find higher exchange rate pass-through, as firms find that the menu costs of price change are more than offset by the loss from having prices far from their desired level. Moreover, the relationship is non-linear. As inflation rises above some threshold, there is no further impact of inflation on pass-through, since all prices are adjusted in each period; pass-through is approximately complete.

Using the estimated $\beta_{j}$ data, we now estimate the second-stage cross-section regression:

$$
\hat{\beta}_{j}=\alpha_{0}+\alpha_{1} \pi_{j}+\alpha_{2} \pi_{j}^{2}
$$

where $\pi$ is the mean inflation rate for country $j$. 
Table 3 illustrates the results. We confirm the increasing but non-linear relationship between trend inflation and exchange rate pass-through. In addition to average inflation, the model allows for the possibility of a link between inflation uncertainty and exchange rate pass-through, because more uncertain inflation should reduce $\kappa$. To explore this, we also add the standard deviation of inflation to the regression, which enters significantly as well.

\begin{tabular}{|c|c|c|}
\hline & (1) & (2) \\
\hline Constant & $\begin{array}{l}0.81^{* * *} \\
(0.01)\end{array}$ & $\begin{array}{l}0.21 * * * \\
(0.01)\end{array}$ \\
\hline Inflat & $\begin{array}{l}0.12 * * * \\
(0.03)\end{array}$ & $\begin{array}{l}0.08^{* *} \\
(0.03)\end{array}$ \\
\hline Inflat sq. & $\begin{array}{l}-0.011 * * * \\
(0.003)\end{array}$ & $\begin{array}{l}-0.008^{* *} \\
(0.004)\end{array}$ \\
\hline St.Dev. Inflat & & $\begin{array}{l}0.37 * * \\
(0.17)\end{array}$ \\
\hline $\mathrm{R}^{2}$ & 0.17 & 0.21 \\
\hline
\end{tabular}

\subsection{Comparing the model and the data}

Our next step is to compare the predictions of our theoretical model with real world data. All data are from the IMF International Financial Statistics. ${ }^{12}$ We estimate the

\footnotetext{
${ }^{12}$ The IFS codes are ..RF.ZF... and 64..XZF... for the exchange rate and the inflation rate respectively. The growth rate of the exchange rate is calculated as $\Delta S_{t j}=\ln \left(S_{t j}\right)-\ln \left(S_{t-1 j}\right)$. All countries for which there are at least 10 annual observations in the post-Bretton Woods period (1970-2007), excluding those countries for which there is little or no nominal exchange rate volatility (defined as s.d. $\left(\Delta S_{t j}\right)<0.05$ ), are included. See Appendix 2 for a full list of countries and estimates of $\beta$.
} 
country-specific exchange rate pass-through coefficients as in (13), and then run the same second-stage regression on the estimates. ${ }^{13}$

Table 4 contains the results of the second-stage regression, including all 144 countries in the sample. First, there is strong evidence that mean inflation tends to increase the rate of exchange rate pass-through, and some evidence that this effect dwindles as inflation rises.

\begin{tabular}{|c|c|c|c|}
\hline \\
\hline \multicolumn{4}{|c|}{$\begin{array}{l}\text { Table 4. Dependent variable: Estimated pass-through } \\
\text { coefficient (all countries). }\end{array}$} \\
\hline \multicolumn{4}{|l|}{ Constant } \\
\hline Inflat & $\begin{array}{l}2.00 * * * \\
(0.28)\end{array}$ & $\begin{array}{l}1.70 * * * \\
(0.33)\end{array}$ & $\begin{array}{c}0.98 * * \\
(0.38)\end{array}$ \\
\hline Inflat sq. & $\begin{array}{l}-0.06 \\
(0.04)\end{array}$ & $\begin{array}{l}-0.08^{*} \\
(0.04)\end{array}$ & $\begin{array}{l}-0.05 \\
(0.04)\end{array}$ \\
\hline St.Dev. Inflat & & $\begin{array}{l}0.13^{*} \\
(0.08)\end{array}$ & $\begin{array}{l}0.18^{* *} \\
(0.07)\end{array}$ \\
\hline $\begin{array}{l}\text { St. Dev Ex } \\
\text { Rate }\end{array}$ & & & $\begin{array}{l}2.44 * * * \\
(0.73)\end{array}$ \\
\hline $\mathrm{R}^{2}$ & 0.67 & 0.67 & 0.70 \\
\hline
\end{tabular}

Table 4 also adds the standard deviation of inflation and exchange rate

depreciation as separate regressors. We find that both variables are significant, even once we control for mean inflation and mean inflation squared, consistent with the degree of volatility or uncertainty being an important determinant of the frequency of price adjustment.

Figure 2 represents the empirical analogue to Figure 1. As we see, the empirical relationship between pass-through and the mean inflation rate is upward sloping, but at a

\footnotetext{
${ }^{13}$ Although this equation is not likely to represent a full specification for inflation determination, it should capture the aggregate influence of exchange rate movements on changes in national price levels. A similar approach is taken by Choudhri and Hakura (2006).
} 
decreasing rate, as in the calibrated model. Note that there is considerably more variation in the relationship in the data than in the model. This is to be expected, given the parsimony of the model.

Figure 2. Pass-through on sample data

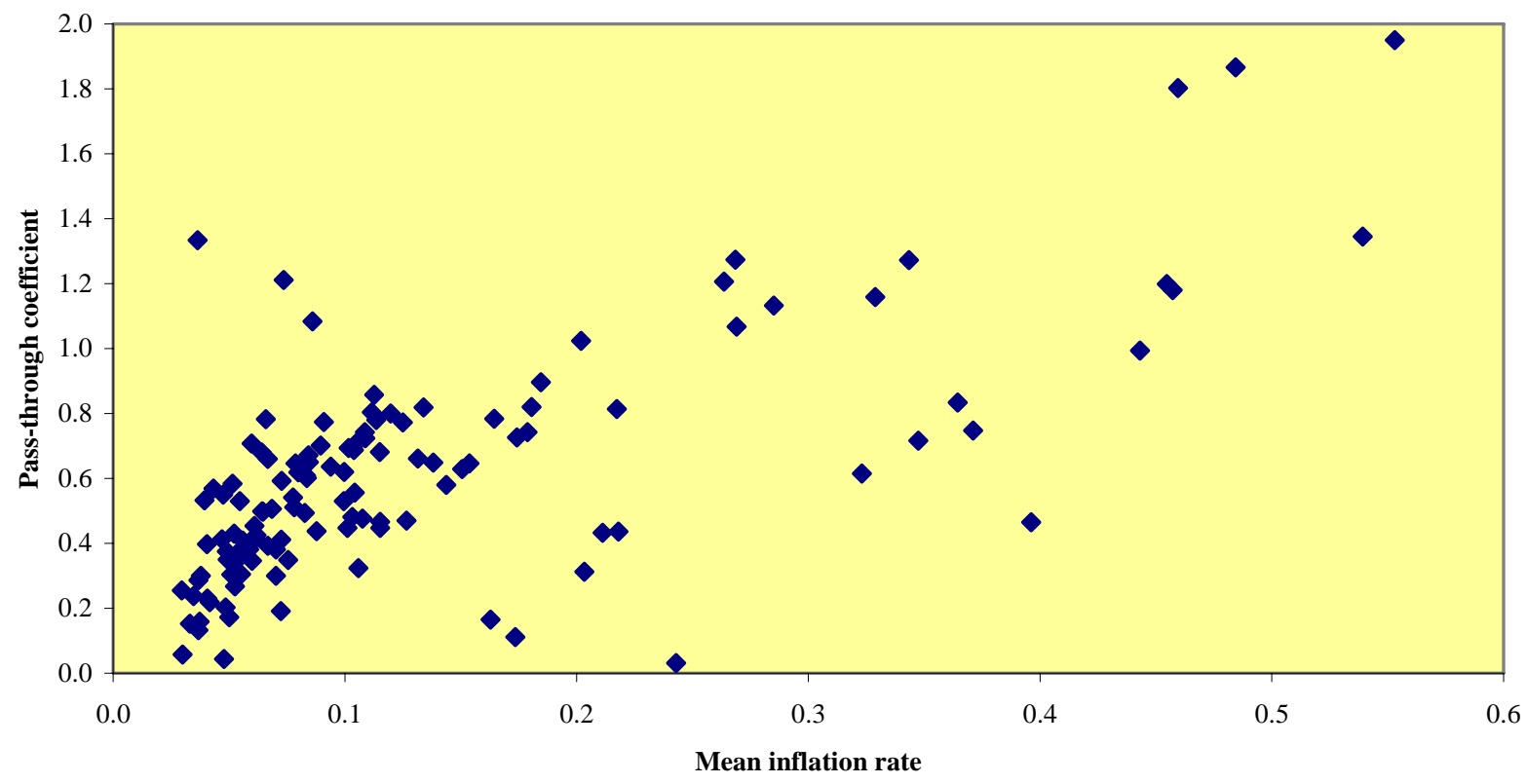

In the above results, the dependent variable includes estimated pass-through coefficients for all countries, and for up to 38 years of data. To confirm the robustness of the results, we consider a number of extensions to our empirical model.

First we exclude high inflation observations, defined as inflation over 50\% annually. Our model may be a more accurate description for economies with low or moderate inflation, since our assumed monetary policy rule (5) may be a poor description of monetary policy during periods of high inflation economies.

Second we estimate our model over sub-samples. Our sample (1970-2007) covers a period in which many economies experienced large changes in the average inflation 
rate. The presence of such structural breaks may bias the results from the second stage regression. We therefore break our sample into four sub-periods (1970-1979, 1980-1989, 1990-1999, 2000-2007) and estimate pass-through using (13) for each sub-period, for each economy. ${ }^{14}$ And third, we combine the above extensions by estimating on subperiods, but excluding high inflation observations.

The results of these robustness checks are contained in Table 5. First we see that now there is now strong statistical evidence of a non-linear relationship between inflation and pass-through as predicted by our model in all cases, with the estimated negative coefficient on inflation squared being highly significant. Again, we also find some evidence that greater volatility of inflation and the exchange rate, as measured by their respective standard deviations, also explains increased exchange rate pass-through as well. ${ }^{15}$ In general, the results support the hypothesis that sticky prices are an important factor in determining exchange rate pass-through at the aggregate level.

\footnotetext{
${ }^{14}$ We drop sub-periods with fewer than 5 observations.

${ }^{15}$ Alternative formulations were also considered. For example, including or excluding an intercept in the first and/or second stage of the estimation has little impact on the reported results. Defining the growth rate of the exchange rate as $\Delta S_{t j}=\left(S_{t j}-S_{t-1 j}\right) / S_{t-1 j}$ (instead of $\left.\Delta S_{t j}=\ln \left(S_{t j}\right)-\ln \left(S_{t-1 j}\right)\right)$ reduces the explanatory power of the second stage regressions (as measured by the $\mathrm{R}^{2}$ ), but does not change the main prediction that the inflation rate has a positive, non-linear relationship with pass-through.
} 


\begin{tabular}{|c|c|c|c|c|c|c|}
\hline & \multicolumn{2}{|c|}{$\begin{array}{l}\text { High inflation } \\
\text { observations dropped }\end{array}$} & \multicolumn{2}{|c|}{$\begin{array}{l}\text { Estimation on sub- } \\
\text { samples }\end{array}$} & \multicolumn{2}{|c|}{$\begin{array}{l}\text { High inflation } \\
\text { observations dropped; } \\
\text { estimation on sub- } \\
\text { samples }\end{array}$} \\
\hline & (1) & (2) & (3) & (4) & (5) & (6) \\
\hline Constant & $\begin{array}{l}0.10 \\
(0.09)\end{array}$ & $\begin{array}{l}0.09 \\
(0.09)\end{array}$ & $\begin{array}{l}0.36^{* * * *} \\
(0.06)\end{array}$ & $\begin{array}{l}0.31^{* * *} \\
(0.07)\end{array}$ & $\begin{array}{l}-0.11^{*} \\
(0.07)\end{array}$ & $\begin{array}{l}-0.14^{* *} \\
(0.07)\end{array}$ \\
\hline Inflat & $\begin{array}{l}6.20 * * * \\
(1.62)\end{array}$ & $\begin{array}{l}5.47 * * * \\
(1.76)\end{array}$ & $\begin{array}{l}1.34^{* * * *} \\
(0.05)\end{array}$ & $\begin{array}{l}0.88^{* * * *} \\
(0.13)\end{array}$ & $\begin{array}{l}9.03^{* * * *} \\
(1.09)\end{array}$ & $\begin{array}{l}7.16^{* * *} \\
(1.19)\end{array}$ \\
\hline Inflat sq. & $\begin{array}{l}-13.45^{* *} \\
(6.30)\end{array}$ & $\begin{array}{l}-12.27^{* * *} \\
(6.40)\end{array}$ & $\begin{array}{l}-0.03 * * * \\
(0.00)\end{array}$ & $\begin{array}{l}-0.03 * * * \\
(0.00)\end{array}$ & $\begin{array}{l}-17.23^{* * *} \\
(3.65)\end{array}$ & $\begin{array}{l}-14.63^{* * *} \\
(3.70)\end{array}$ \\
\hline $\begin{array}{l}\text { St.Dev. } \\
\text { Inflat }\end{array}$ & & $\begin{array}{l}1.01 \\
(0.89)\end{array}$ & & $\begin{array}{l}0.19 * * * \\
(0.06)\end{array}$ & & $\begin{array}{l}2.59^{* * * *} \\
(0.77)\end{array}$ \\
\hline $\begin{array}{l}\text { St. Dev } \\
\text { Ex Rate }\end{array}$ & & $\begin{array}{l}-0.04 \\
(0.08)\end{array}$ & & $\begin{array}{l}0.61^{* *} \\
(0.26)\end{array}$ & & $\begin{array}{l}0.18^{*} \\
(0.09)\end{array}$ \\
\hline $\mathrm{R}^{2}$ & 0.27 & 0.28 & 0.74 & 0.75 & 0.31 & 0.34 \\
\hline Obs. & 141 & 141 & 392 & 392 & 365 & 365 \\
\hline
\end{tabular}

Standard errors are given in parentheses. *, **, and $* * *$ indicate significance at the $10 \%, 5 \%$, and $1 \%$ levels respectively. In columns 1-2, all observations with inflation greater than 50\% are dropped; in columns 3-4 estimation is performed on 4 subsamples: 1970-1979; 1980-1989; 1990-1999 and 2000-2007; and in columns 5-6 high inflation observations (> 50\%) are dropped, and estimation is performed on subsamples. In columns 3-6, pass-through coefficients estimated on sub-samples with fewer than 5 observations are dropped from the second stage.

A comparison of Figures 1 and 2, Table 3 and Tables 4-5 indicates that the quantitative implications of the model are strikingly consistent with the empirical properties of exchange rate pass-through across countries. Pass-through is higher for higher inflation countries, both in the model and the data, and the relationship is nonlinear. As inflation rises, the increase in pass-through tends to diminish. Given that the model is calibrated to match the configuration of shocks for each country, these results suggest that nominal price rigidity represents a key element in the understanding of exchange rate pass-through. 


\section{Section 5. Conclusions}

In this paper, we have argued that low exchange rate pass-through is at least partly attributable to slow adjustment of nominal prices. In addition, the rate of passthrough is sensitive to the monetary policy regime, precisely because the degree of price stickiness itself is endogenous to the monetary regime. Our model shows how passthrough in a small open economy is determined by structural features of the economy, such as the persistence of shocks, and the degree of price stickiness. When firms can adjust their frequency of price changes, we find that 'looser' monetary policy leads to more frequent price changes, and higher pass-through. The empirical results provide strong support for the presence of price stickiness in determining the degree of passthrough. In particular, both mean inflation and mean exchange rate depreciation tend to increase pass-through, but in a non-linear fashion, as suggested by the model. For sufficiently high inflation rates (or mean exchange rate depreciation rates), all prices are adjusted in every period, and exchange rate pass-through is complete.

In an overall sense, the paper emphasizes the importance of taking account of the endogeneity of exchange rate pass-through in designing monetary policy for a small open economy. 


\section{References}

Backus, David K., Patrick K. Kehoe and Finn E. Kydland (1995) "International Business Cycles: Theory vs. Evidence.” In Frontiers of Business Cycle Research, ed. Thomas F. Cooley, Princeton University Press, Princeton.

Bailliu, Jeannine N. and Eiji Fujii (2004) "Exchange Rate Pass-Through and the Inflation Environment in Industrialized Countries: An Empirical Investigation.” Bank of Canada Working Paper 21.

Ball, Laurence, N. Gregory Mankiw and David Romer (1988) “The New Keynesian Economics and the Output-Inflation Trade-off.” Brookings Papers on Economic Activity, 0(1), 1-65.

Ball, Laurence and N. Gregory Mankiw (1994) "Asymmetric Price Adjustment and Economic Fluctuations.” Economic Journal, 104(423), 247-261.

Betts, Caroline M. and Timothy J. Kehoe (2001) "Real Exchange Rate Movements and the Relative Price of Non-traded Goods.” Mimeo.

Burstein, Ariel T., Martin Eichenbaum and Sergio Rebelo (2002) "Why are Rates of Inflation so Low after Large Devaluations?” NBER Working Paper 8748.

Burstein, Ariel T., Joao C. Neves and Sergio Rebelo (2003) "Distribution Costs and Real Exchange Rate Dynamics during Exchange-Rate-Based Stabilizations.” Journal of Monetary Economics, 50(6), 1189-214.

Calvo, Guillermo A. (1983) “Staggered Prices in a Utility-maximizing Framework.” Journal of Monetary Economics, 12(3), 383-98.

Calvo, Guillermo A. and Carmen M. Reinhart (2002) “Fear of floating.” Quarterly Journal of Economics, 117(2), 379-408. 
Campa, Jose Manuel and Linda S. Goldberg (2005) “Exchange Rate Pass-through into Import Prices.” The Review of Economics and Statistics, 87(4), 679-690.

Choudhri, Ehsan U. and Dalia S. Hakura (2006) “Exchange Rate Pass-through to Domestic Prices: Does the Inflationary Environment Matter?” Journal of International Money and Finance, 25(4), 614-639.

Choudhri, Eshan U., Hamid Faruqee, and Dalia S. Hakura (2005) “Explaining the Exchange Rate Pass-through in Different Prices.” Journal of International Economics, 65(2), 349-374.

Christiano, Lawrence J., Martin Eichenbaum and Charles L. Evans (1999) "Monetary Policy Shocks: What Have we Learned and to What End?” in: J. B. Taylor \& M. Woodford (ed.), Handbook of Macroeconomics, edition 1, volume 1, chapter 2, 65148.

Christiano, Lawrence J., Martin Eichenbaum and Charles L. Evans (2005) "Nominal Rigidities and the Dynamic Effects of a Shock to Monetary Policy.” Journal of Political Economy, 113(1), 1-45.

Christofides, Louis N. and Audrey Laporte (2002) “Menu Costs, Nominal Wage Revisions and Intracontract Wage Behavior.” Industrial Relations, 41(2), 287-303. Clarida, Richard, Jordi Gali and Mark Gertler (1998) “Monetary Policy Rules in Practice: Some International Evidence.” European Economic Review, 42(6), 1033-1067. Clarida, Richard, Jordi Gali and Mark Gertler (1999) “The Science of Monetary Policy: A New Keynesian Perspective.” Journal of Economic Literature, 37(4), 1661-1707. Corsetti, Giancarlo and Luca Dedola (2005) “Macroeconomics of International Price Discrimination.” Journal of International Economics, 67(1), 129-156. 
Devereux, Michael B. (2001) "Monetary Policy, Exchange Rate Flexibility, and Exchange Rate Pass-through.” In Revising the Case for Flexible Exchange Rates, Bank of Canada.

Devereux, Michael B., Charles Engel and Peter E. Storgaard (2004) "Endogenous Exchange Rate Pass-through when Nominal Prices are set in Advance.” Journal of International Economics, 63(2), 263-291.

Devereux, Michael B., Philip Lane and Juanyi Xu (2006) “Exchange Rate Rules and Monetary Policy for Emerging Market Economies”, Economic Journal, 116(511), 478-506.

Devereux, Michael B. and James Yetman (2002), "Menu Costs and the Long Run Output Inflation Trade-off” Economics Letters, 76, 95-100.

Dotsey, Michael, Robert G. King and Alexander Wolman (1999) "State Dependent Pricing and the General Equilibrium Dynamics of Money and Output.” Quarterly Journal of Economics, 114(2), 655-690.

Engel, Charles (2002) “The Responsiveness of Consumer Prices to Exchange Rates: A Synthesis of some New Open-Economy Macro Models.” The Manchester School, 70 (Supplement), 1-15.

Fay, Robert and Sébastien Lavoie (2002) "How Certain Are We About the Role of Uncertainty in the Labour Contract Duration Decision? Evidence for Canada and Implications.” Bank of Canada.

Flamino, Alessandro (2007) "Inflation Targeting and Exchange Rate Pass-Through.” Journal of International Money and Finance, 26(7), 1113-1150. 
Hau, Harold (2000) “Exchange Rate Determination: The Role of Factor Price Rigidities and Nontradeables.” Journal of International Economics, 50(2), 421-47.

Heston, Alan, Robert Summers and Bettina Aten (2006) "Penn World Table Version 6.2.” Center for International Comparisons of Production, Income and Prices at the University of Pennsylvania

Judd, John P. and Glen Rudebusch (1998) “Taylor’s Rule and the Fed: 1970-1997”, Federal Reserve Bank of San Francisco, Economic Review, 3, 2-16.

Levin, Andrew, and Tack Yun (2007), "Reconsidering the Natural Rate Hypothesis in a New Keynesian Framework”, Journal of Monetary Economics, 54, 1336-1371.

Lucas, Robert E. and Mikhail Golosov (2007) “Menu Costs and Phillips Curves.” Journal of Political Economy, 115(2), 171-199.

Monacelli, Tommaso (2001) “New International Arrangements and the Exchange Rate.” International Journal of Finance and Economics, 6(4), 389-400.

Monacelli, Tommaso (2005) "Monetary Policy in a Low Pass-through Environment.” Journal of Money, Credit and Banking, 37(6), 1047-66.

Nelson, Edward (2001) “UK Monetary Policy 1972-97: a guide using Taylor Rules.” CEPR Discussion Paper 2931.

Riksbank (2001) “Has Price Flexibility Changed?” Inflation Report, 3, 22-24.

Romer, David (1990) “Staggered Price Setting with Endogenous Frequency of Adjustment, Economics Letters, 32, 2005-210.

Taylor, John B. (2000) "Low Inflation, Pass-Through, and the Pricing Power of Firms.” European Economic Review, 44(7), 1389-1408. 
Vroman Susan B. (1989) "Inflation Uncertainty and Contract Duration.” The Review of Economics and Statistics, 71(4), 677-681.

Wash, Carl E. (1998) “Monetary Theory and Policy.” MIT Press.

Woodford, Michael (2003) "Interest and Prices: Foundations of a Theory of Monetary Policy.” Princeton University Press.

Yetman, James (2003) “Fixed Prices versus Predetermined Prices and the Equilibrium Probability of Price Adjustment.” Economics Letters, 80(3), 421-427.

Yun, Tack (1996) “Nominal Price Rigidity, Money Supply Endogeneity, and Business Cycles.” Journal of Monetary Economics, 37(2), 345-70.

Zbaracki, Mark J., Mark Ritson, Daniel Levy, Shantanu Dutta and Mark Bergen (2004), "Managerial and Customer Costs of Price Adjustment: Direct Evidence from Industrial Markets.” Review of Economics and Statistics, 86(2), 514-533. 


\section{Appendix 1 The model}

Take a small economy where agents consume only imported goods, ${ }^{16}$ and produce an export good using only labor. The representative agent has preferences given by

$$
U=E_{t} \sum_{j=0}^{\infty} \beta^{j}\left(\frac{C_{t+j}^{1-\sigma}}{1-\sigma}-\frac{\eta}{1+\psi} H_{t+j}^{1+\psi}\right)
$$

where $C_{t}=\left(\int_{i=0}^{1} C_{t}(i)^{1-\frac{1}{\lambda}} d i\right)^{\frac{1}{1-\frac{1}{\lambda}}}$ is consumption of the imported good, and $H_{t}$ is the labor supply. Defining the CPI as $P_{t}=\left(\int_{i=0}^{1} P_{t}(i)^{1-\lambda} d i\right)^{\frac{1}{1-\lambda}}$ (the price index for imported goods), the demand for imported goods varieties given above may be derived.

Domestic consumers face a budget constraint given by

$$
S_{t} B_{t+1}^{*}+B_{t+1}+P_{t} C_{t}=Q_{t} Y_{t}+S_{t} B_{t}^{*}\left(1+i_{t}^{*}\right)+\left(1+i_{t}\right) B_{t}+\Pi_{t} .
$$

That is, the home consumer receives income from the sale of export goods $Y_{t}$, at price $Q_{t}$, interest payments on bonds, and profits from the importing goods firms. This income is used to consume imported goods, and to invest in domestic and foreign-currency denominated bonds, repaying nominal interest rates $i_{t}$ and $i_{t}^{*}$ respectively. A simplifying feature of the model is that, because households consume only imported goods, we do not need to focus on the domestic production sector in order to study exchange rate passthrough.

The optimality conditions for the home consumer include the Euler equations

\footnotetext{
${ }^{16}$ We abstract from non-traded goods. The effect of non-traded goods on exchange rate pass-through is well understood (e.g. Hau 2000). Our aim is to focus specifically on the implications of menu costs for exchange rate pass-through.
} 


$$
\begin{gathered}
\frac{1}{1+i_{t}^{*}}=E_{t} \beta \frac{C_{t}^{\sigma} P_{t} S_{t+1}}{C_{t+1}^{\sigma} P_{t+1} S_{t}}, \\
\frac{1}{1+i_{t}}=E_{t} \beta \frac{C_{t}^{\sigma} P_{t}}{C_{t+1}^{\sigma} P_{t+1}} .
\end{gathered}
$$

Suppose that monetary policy is described by an interest-rate rule,

$$
\left(1+i_{t}\right)=\Phi \exp \left(v_{t}\right)\left(\frac{P_{t}}{P_{t-1}}\right)^{\delta},
$$

where $\Phi$ is a constant, and $v_{t}$ is an interest-rate shock to the policy rule. The monetary authority sets interest rates to respond to CPI inflation, with the elasticity of response given by $\delta$. Let $\delta>1$, so that the monetary authority follows a policy of increasing the ex-post real interest rate in response to a rise in current inflation. 


\section{Appendix 2 Pass-through coefficients}

\begin{tabular}{|c|c|c|c|c|c|c|c|c|c|c|c|c|c|c|}
\hline Country & Obs. & $\beta$ & Signif. & $\pi$ & Country & Obs. & $\beta$ & Signif. & $\pi$ & Country & Obs. & $\beta$ & Signif. & $\pi$ \\
\hline Albania & 15 & 1.27 & 0.001 & 0.27 & Ghana & 36 & 0.72 & 0.000 & 0.35 & Nicaragua & 35 & 12.91 & 0.000 & 7.90 \\
\hline Algeria & 37 & 0.53 & 0.000 & 0.10 & Greece & 30 & 0.80 & 0.000 & 0.12 & Niger & 37 & 0.43 & 0.000 & 0.05 \\
\hline Angola & 17 & 6.16 & 0.000 & 6.40 & Guatemala & 37 & 0.74 & 0.000 & 0.11 & Nigeria & 37 & 0.31 & 0.013 & 0.20 \\
\hline Argentina & 37 & 4.73 & 0.000 & 2.52 & Guinea-Bissau & 20 & 1.07 & 0.000 & 0.27 & Norway & 37 & 0.35 & 0.000 & 0.05 \\
\hline Armenia & 14 & 14.82 & 0.000 & 3.92 & Guyana & 13 & 0.78 & 0.002 & 0.07 & Pakistan & 37 & 0.44 & 0.000 & 0.09 \\
\hline Australia & 37 & 0.41 & 0.000 & 0.06 & Haiti & 37 & 0.82 & 0.000 & 0.13 & Papua New Guinea & 36 & 0.51 & 0.000 & 0.08 \\
\hline Austria & 28 & 0.13 & 0.091 & 0.04 & Honduras & 37 & 0.68 & 0.000 & 0.12 & Paraguay & 37 & 0.58 & 0.000 & 0.14 \\
\hline Azerbaijan, Rep. Of & 15 & 6.22 & 0.000 & 2.61 & Hungary & 35 & 0.86 & 0.000 & 0.11 & Peru & 37 & 11.39 & 0.000 & 3.47 \\
\hline Bangladesh & 21 & 0.71 & 0.000 & 0.06 & Iceland & 37 & 1.02 & 0.000 & 0.20 & Philippines & 37 & 0.80 & 0.000 & 0.11 \\
\hline Belarus & 12 & 1.49 & 0.000 & 3.30 & India & 37 & 0.65 & 0.000 & 0.08 & Poland & 35 & 2.27 & 0.000 & 0.39 \\
\hline Belgium & 28 & 0.22 & 0.007 & 0.04 & Indonesia & 37 & 0.47 & 0.000 & 0.13 & Portugal & 28 & 0.78 & 0.000 & 0.11 \\
\hline Benin & 15 & 0.45 & 0.000 & 0.06 & Iran, I.R. Of & 37 & 0.11 & 0.060 & 0.17 & Romania & 17 & 1.72 & 0.000 & 0.77 \\
\hline Bhutan & 26 & 0.62 & 0.000 & 0.08 & Ireland & 28 & 0.59 & 0.000 & 0.07 & Russia & 14 & 2.03 & 0.000 & 1.11 \\
\hline Bolivia & 37 & 16.77 & 0.000 & 3.72 & Israel & 37 & 1.80 & 0.000 & 0.46 & Rwanda & 37 & 0.62 & 0.000 & 0.10 \\
\hline Botswana & 33 & 0.48 & 0.000 & 0.10 & Italy & 28 & 0.54 & 0.000 & 0.08 & Samoa & 37 & 0.61 & 0.000 & 0.08 \\
\hline Brazil & 27 & 5.53 & 0.000 & 4.33 & Jamaica & 36 & 0.82 & 0.000 & 0.18 & Senegal & 37 & 0.35 & 0.000 & 0.06 \\
\hline Bulgaria & 22 & 2.71 & 0.000 & 0.89 & Japan & 37 & 0.15 & 0.065 & 0.03 & Serbia, Republic Of & 10 & 0.47 & 0.035 & 0.40 \\
\hline Burkina Faso & 37 & 0.30 & 0.000 & 0.05 & Jordan & 37 & 0.66 & 0.000 & 0.07 & Seychelles & 37 & 0.68 & 0.000 & 0.06 \\
\hline Burundi & 37 & 0.71 & 0.000 & 0.11 & Kazakhstan & 13 & 1.87 & 0.001 & 1.57 & Sierra Leone & 37 & 1.16 & 0.000 & 0.33 \\
\hline Cambodia & 13 & 0.57 & 0.000 & 0.04 & Kenya & 37 & 0.77 & 0.000 & 0.13 & Slovak Republic & 14 & 0.19 & 0.354 & 0.07 \\
\hline Cameroon & 37 & 0.38 & 0.000 & 0.07 & Korea & 37 & 0.60 & 0.000 & 0.08 & Slovenia & 14 & 0.64 & 0.001 & 0.09 \\
\hline Cape Verde & 24 & 0.20 & 0.092 & 0.05 & Kyrgyz Republic & 12 & 0.66 & 0.000 & 0.13 & Solomon Islands & 36 & 0.69 & 0.000 & 0.10 \\
\hline Central African Rep. & 27 & 0.24 & 0.001 & 0.03 & Lao People S Dem.Rep & 19 & 1.21 & 0.000 & 0.26 & South Africa & 37 & 0.45 & 0.000 & 0.10 \\
\hline Chad & 24 & 0.53 & 0.000 & 0.04 & Latvia & 15 & -1.62 & 0.190 & 0.30 & Spain & 28 & 0.49 & 0.000 & 0.08 \\
\hline Chile & 37 & 1.95 & 0.000 & 0.55 & Lebanon & 24 & 1.87 & 0.000 & 0.48 & Sri Lanka & 37 & 0.56 & 0.000 & 0.10 \\
\hline China,P.R.: Mainland & 21 & 0.50 & 0.002 & 0.06 & Lesotho & 34 & 0.47 & 0.000 & 0.12 & Sudan & 36 & 0.75 & 0.000 & 0.37 \\
\hline China,P.R.:Macao & 19 & 1.33 & 0.000 & 0.04 & Liberia & 19 & 1.21 & 0.000 & 0.07 & Suriname & 36 & 0.83 & 0.000 & 0.36 \\
\hline Colombia & 37 & 0.90 & 0.000 & 0.18 & Libya & 36 & 0.04 & 0.659 & 0.05 & Swaziland & 36 & 0.48 & 0.000 & 0.11 \\
\hline Congo, Dem. Rep. Of & 35 & 19.54 & 0.000 & 9.88 & Lithuania & 15 & 4.17 & 0.000 & 0.38 & Sweden & 37 & 0.31 & 0.000 & 0.06 \\
\hline Congo, Republic Of & 22 & 0.41 & 0.000 & 0.05 & Luxembourg & 28 & 0.23 & 0.002 & 0.04 & Switzerland & 37 & 0.06 & 0.313 & 0.03 \\
\hline Costa Rica & 37 & 0.78 & 0.000 & 0.16 & Macedonia, Fyr & 13 & -0.01 & 0.941 & 0.12 & Syrian Arab Republic & 36 & 0.45 & 0.001 & 0.12 \\
\hline Cote D Ivoire & 37 & 0.30 & 0.001 & 0.07 & Madagascar & 37 & 0.65 & 0.000 & 0.14 & Tanzania & 37 & 0.74 & 0.000 & 0.18 \\
\hline Croatia & 15 & 6.91 & 0.000 & 1.38 & Malawi & 27 & 0.81 & 0.000 & 0.22 & Thailand & 37 & 0.53 & 0.000 & 0.05 \\
\hline Cyprus & 37 & 0.35 & 0.000 & 0.05 & Malaysia & 37 & 0.30 & 0.001 & 0.04 & Togo & 37 & 0.43 & 0.000 & 0.06 \\
\hline Czech Republic & 14 & 0.17 & 0.359 & 0.05 & Maldives & 24 & 1.08 & 0.002 & 0.09 & Tonga & 31 & 0.65 & 0.000 & 0.08 \\
\hline Denmark & 37 & 0.27 & 0.001 & 0.05 & Mali & 19 & 0.26 & 0.001 & 0.03 & Trinidad And Tobago & 37 & 0.70 & 0.000 & 0.09 \\
\hline Dominican Republic & 37 & 0.63 & 0.000 & 0.15 & Malta & 37 & 0.29 & 0.001 & 0.04 & Tunisia & 24 & 0.38 & 0.001 & 0.05 \\
\hline Egypt & 36 & 0.32 & 0.000 & 0.11 & Mauritania & 18 & 0.39 & 0.000 & 0.07 & Turkey & 37 & 1.18 & 0.000 & 0.46 \\
\hline El Salvador & 37 & 0.72 & 0.000 & 0.11 & Mauritius & 37 & 0.77 & 0.000 & 0.09 & Uganda & 27 & 0.99 & 0.000 & 0.44 \\
\hline Equatorial Guinea & 19 & 0.40 & 0.001 & 0.04 & Mexico & 37 & 1.13 & 0.000 & 0.29 & Ukraine & 14 & 3.49 & 0.000 & 4.15 \\
\hline Estonia & 14 & 0.17 & 0.748 & 0.16 & Moldova & 12 & 0.65 & 0.002 & 0.15 & United Kingdom & 37 & 0.51 & 0.000 & 0.07 \\
\hline Ethiopia & 37 & 0.35 & 0.014 & 0.08 & Mongolia & 15 & 1.27 & 0.000 & 0.34 & Uruguay & 37 & 1.20 & 0.000 & 0.45 \\
\hline Fiji & 37 & 0.50 & 0.000 & 0.06 & Morocco & 37 & 0.41 & 0.000 & 0.06 & Vanuatu & 30 & 0.58 & 0.000 & 0.05 \\
\hline Finland & 28 & 0.39 & 0.002 & 0.06 & Mozambique & 22 & 0.61 & 0.000 & 0.32 & Venezuela, Rep. Bol. & 37 & 0.03 & 0.366 & 0.24 \\
\hline France & 28 & 0.34 & 0.000 & 0.05 & Myanmar & 37 & 0.73 & 0.060 & 0.17 & Vietnam & 10 & 0.55 & 0.010 & 0.05 \\
\hline Gabon & 37 & 0.38 & 0.000 & 0.06 & Nepal & 37 & 0.67 & 0.000 & 0.08 & Yemen, Republic Of & 16 & 0.43 & 0.005 & 0.21 \\
\hline Gambia, The & 35 & 0.69 & 0.000 & 0.10 & Netherlands & 28 & 0.16 & 0.049 & 0.04 & Zambia & 22 & 1.34455 & $5.57 \mathrm{E}-10$ & 0.53921 \\
\hline Georgia & 11 & 0.44 & 0.017 & 0.22 & New Zealand & 37 & 0.41 & 0.000 & 0.07 & Zimbabwe & 36 & 2.39394 & 4.39E-10 & 7.17974 \\
\hline
\end{tabular}

